\title{
Apakah Sinergis Pengungkapan Informasi Lingkungan dan Inovasi Teknologi Bisa Berdampak pada Kinerja Keuangan Perusahaan Manufaktur?
}

\section{Andro Geraldo Lumangkun ${ }^{*}$, Farah Margaretha Leon ${ }^{2}$}

1,2 Fakultas Ekonomika dan Bisnis, Universitas Trisakti, Indonesia

\section{ART ICLE INF O}

\section{Article history:}

Received August 22, 2021

Revised August 29, 2021

Accepted October 14, 2021

Available online October 25, 2021

Kata Kunci:

Informasi Lingkungan, Inovasi

Teknologi, Kinerja Keuangan

Keywords:

Environmental Information, Technological Innovation, Financial Performance

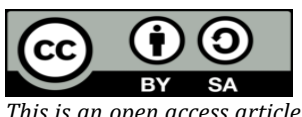

This is an open access article under the $\underline{C C}$ BY-SA license.

Copyright (C) 2021 by Author. Published by Universitas Pendidikan Ganesha.

\section{A B S TRACT}

\begin{abstract}
A B S T R A K
Pada dasarnya aktifitas operasional yang dilakukan perusahaan manufaktur tersebut berhubungan langsung dengan masyarakat dan lingkungan sekitarnya, sehingga dampak dari aktifitas perusahaan tidak hanya dirasakan oleh pihak internal perusahaan tetapi juga dirasakan oleh pihak eksternal, yakni masyarakat yang berada di lingkungan sekitar perusahaan. Penelitian ini bertujuan untuk menganalisis pengaruh pengungkapan informasi lingkungan dan inovasi teknologi dan sinergis antara pengungkapan informasi lingkungan dan inovasi teknologi terhadap kinerja keuangan pada perusahaan manufaktur di Indonesia yang sudah go public. Data diperoleh dengan menggunakan metode purposive sampling sehingga diperoleh 28 perusahaan manufaktur yang telah go public dan memenuhi kriteria pada periode 2015 sampai 2019. Penelitian ini menggunakan metode analisis regresi data panel dengan menggunakan E-views. Data yang akan digunakan dalam uji regresi harus lolos dalam uji stasioner. Uji stasioner dalam penelitian ini diamati melalui metode Uji Phillips Person. Hasil penelitian menunjukkan bahwa tidak adanya pengaruh pengungkapan informasi lingkungan, inovasi teknologi dan sinergis antara pengungkapan informasi lingkungan dan inovasi teknologi terhadap kinerja keuangan perusahaan manufaktur di Indonesia. Manajer keuangan dan investor perlu untuk meningkatkan utang dan pendapatan kotor perusahaan untuk meningkatkan kinerja keuangan dan memperhatikan nilai aset yang dimiliki karena dapat menurunkan kinerja keuangan.
\end{abstract}

The operational activities carried out by the manufacturing company are directly related to the community and the surrounding environment. The impact of the company's activities is not only felt by the company's internal parties but also by external parties, namely the community around the company. This study aims to analyze the effect of environmental information disclosure and technological innovation and the synergism between environmental information disclosure and technological innovation on the financial performance of manufacturing companies in Indonesia that have gone public. The data was obtained using the purposive sampling method so that 28 manufacturing companies that have gone public and met the criteria for the 2015 to 2019 period were obtained. This study uses the panel data regression analysis method using E-views. The data to be used in the regression test must pass the static test. The stationary test in this study was observed through the Phillips Person Test method. The study results indicate that there is no effect of environmental information disclosure, technological innovation, and synergies between environmental information disclosure and technological innovation on the financial performance of manufacturing companies in Indonesia. Financial managers and investors need to increase the company's debt and gross income to improve financial performance and pay attention to the value of assets owned because it can reduce financial performance.

\section{PENDAHULUAN}

Pertumbuhan perusahaan merupakan kemampuan perusahaan untuk meningkatkan size. Pertumbuhan (growth) adalah seberapa jauh perusahaan menempatkan diri dalam system ekonomi secara keseluruhan atau sistem ekonomi untuk industri yang sama (Kusa et al., 2022; Mitrega et al., 2021; Peng \& Liu, 2018). Pertumbuhan perusahaan sangat diharapkan oleh banyak pihak baik internal maupun eksternal, karena pertumbuhan yang baik memberi tanda bagi perkembangan perusahaan (Mahanani et al., 2017; Wardani \& Purwaningrum, 2018). Pertumbuhan suatu perusahaan merupakan tanda perusahaan memiliki aspek yang menguntungkan, karena dianggap mampu menghasilkan keuntungan yang lebih baik dari waktu ke waktu (Bour et al., 2019; Mirza et al., 2021). Pendapatan juga dapat diberi label sebagai nilai perusahaan dan dapat digunakan untuk menentukan evaluasi perusahaan itu sendiri 
(Azhari \& Agus, 2016; Vítková et al., 2017). Pertumbuhan perusahaan bisa diukur melalui laba operasi kotor yang diperoleh perusahaan di periode tertentu. Salah satu jenis perusahaan yang terdapat di Indonesia yaitu manufakur.

Industri manufaktur menjadi sektor yang aktifitas operasionalnya mengolah bahan baku menjadi produk yang sifatnya berbeda sama sekali dengan bahan bakunya (Purwanti \& Sugiyarti, 2017; Triyono et al., 2020; Yuniarti, 2012). Pada dasarnya aktifitas operasional yang dilakukan perusahaan manufaktur tersebut berhubungan langsung dengan masyarakat dan lingkungan sekitarnya, sehingga dampak dari aktifitas perusahaan tidak hanya dirasakan oleh pihak internal perusahaan tetapi juga dirasakan oleh pihak eksternal, yakni masyarakat yang berada di lingkungan sekitar perusahaan. Pencemaran tidak hanya terjadi di kawasan industri, tetapi juga di lingkungan penduduk (Khairul et al., 2020; Siregar \& Kiswiranti, 2020; Verawaty et al., 2020). Oleh karena itu, perusahaan harus mengeluarkan sejumlah biaya untuk meminimalisir dampak yang akan diberikan. Hal ini menandakan bahwa pengungkapan akan informasi kinerja bisnis perusahaan sangat diharuskan sebagai bentuk pertanggungjawaban dan transparansi. Perusahaan yang terdaftar perlu mempersiapkan dan mempublikasikan kinerja bisnis mereka secara berkala dalam bentuk laporan dimana proses ini disebut sebagai pengungkapan informasi perusahaan (Anis, 2017; Gong, 2019).

Pengungkapan informasi merupakan tindakan yang dilakukan oleh perusahaan dalam rangka transparansi yang berkaitan dengan bsinis perusahaan yang sedang dijalankan (Dewi \& Sedana, 2019; Dutrianda \& Pangaribuan, 2020). Perusahaan melakukan pengungkapan informasi dengan tujuan untuk membangun image perusahaan dan mendapatkan perhatian baik dari investor maupun masyarakat (Efrizon, 2019; Fadrianto \& Mulyani, 2018; Wijayanti et al., 2016). Berbagai jenis informasi yang bisa diungkapkan oleh perusahaan dan menjadi bentuk transparansi. Beberapa diantaranya adalah pengungkapan informasi mengenai lingkungan yang digambarkan melalui program Coporate Social Responsibility (CSR) dan inovasi teknologi atau yang biasa disebut Research and Development (R\&D). Dari semua jenis pengungkapan informasi di perusahaan, perlindungan lingkungan dan inovasi teknologi dapat secara intuitif mencerminkan daya saing inti dan potensi pengembangan perusahaan (Xia dan Wang, 2020).

Dari semua jenis pengungkapan informasi di perusahaan, perlindungan lingkungan dan inovasi teknologi dapat secara intuitif mencerminkan daya saing inti dan potensi pengembangan perusahaan (Xia dan Wang, 2020). Pengungkapan informasi lingkungan yang dilakukan oleh perusahaan merupakan tuntutan yang ditujukan oleh stackholder yang harus di wujudkan sebagai salah satu respon perusahaan (Ikhwandarti et al., 2010; Sihombing et al., 2017). Selain itu, pengungkapan informasi lingkungan bisa menjadi bukti pertanggungjawaban perusahaan kepada masyarakat terkait dengan dampak yang akan disebabkan dan bagaimana usaha perusahaan dalam menangani dampak tersebut. Bagi perusahaan go public, salah satu cara memperoleh dana adalah dengan memperdagangkan sahamnya di Bursa (Efrizon, 2019; Kusuma, 2016; Sharif et al., 2020). Persaingan yang semakin ketat di dunia usaha mendorong perusahaan khususnya perusahaan yang go public untuk lebih menunjukkan keunggulan kompetitifnya sehingga para investor tertarik untuk menanamkan modalnya pada perusahaan tersebut. Transparansi menjadi sesuatu yang sering dipuji sebagai sesuatu yang berharga bagi konsumen dan investor (Minutolo, et. al., 2019). Oleh karena itu, laporan keuangan bisa dijadikan sumber pengukuran kinerja keuangan dan bentuk transparansi perusahaan.

Berdasarkan latar belakang di atas dan penelitian terdahulu, peneliti tertarik untuk melakukan penelitian ulang di Indonesia karena penelitian sebelumnya di lakukan di China yang menunjukkan bahwa adanya dampak sinergis pengungkapan lingkungan dan inovasi teknologi terhadap kinerja keuangan perusahaan batubara. Pengungkapan informasi lingkungan dan inovasi teknologi menjadi bagian penting bagi perusahaan untuk meyakinkan investor dan masyarakat akan bisnis yang dijalankan. Oleh karena itu, penelitian ini bertujuan untuk melihat apakah adanya pengaruh pengungkapan informasi lingkungan dan inovasi teknologi perusahaan manufaktur di Indonesia pada tahun 2015 sampai 2019 dan apakah dengan adanya sinergis dua pengungkapan ini bisa memberikan dampak sehingga kinerja keuangan perusahaan bisa semakin menurun.

\section{METODE}

Metode Pengumpulan data yang digunakan adalah pengumpulan data sekunder. Data sekunder merupakan data yang diperoleh penelitian secara tidak langsung atau sumber yang telah dipublikasikan sehingga data tersebut telah tersedia. Sumber data pada penelitian ini diperoleh dari website Bursa Efek Indonesia (www.idx.co.id) dan dari masing-masing website perusahaan yang dipilih sebagai sampel. Data penelitian ini terdiri dari semua perusahaan manufaktur yang terdaftar di Bursa Efek Indonesia selama periode 2015-2019. Metode penarikan sampel yang dilakukan dalam penelitian ini dengan cara purposive 
sampling, dari metode tersebut didapatkan sampel penelitian sebanyak 28 perusahaan pada sektor manufaktur yang telah memenuhi kritertia tertentu. Kriteria sampel disajikan pada Tabel 1.

Tabel 1. Kriteria Penarikan Sampel

\begin{tabular}{lc}
\hline \multicolumn{1}{c}{ Keterangan } & Jumlah \\
\hline Perusahaan-perusahaan manufaktur yang telah go-public dan terdaftar di Bursa Efek & 178 \\
Indonesia (BEI) untuk periode 2015-2019. & \\
$\begin{array}{l}\text { Perusahaan manufaktur yang tidak memiliki kelengkapan data yang akan digunakan } \\
\text { dalam penelitian. }\end{array}$ & (63) \\
$\begin{array}{l}\text { Perusahaan manufaktur yang tidak melaporkan biaya lingkungan dan R\&D untuk } \\
\text { periode 2015-2019. }\end{array}$ & (87) \\
Jumlah data yang dapat dijadikan sebagai sampel & 28 \\
\hline
\end{tabular}

Identifikasi variabel pada penelitian ini yaitu untuk mengetahui hubungan antara variabel independen (Pengungkapan Informasi Lingkungan dan Pengungkapan Informasi Inovasi Teknologi) terhadap Variabel Dependen (Kinerja Keuangan) dengan adanya variabel kontrol (ukuran perusahaan, aset dan liabilitas, pertumbuhan perusahaan dan konsentrasi kepemilikan), yang masing-masing variabel pengukurannya disajikan pada Tabel 2.

Tabel 2. Variabel dan Pengukuran

\begin{tabular}{|c|c|c|c|c|}
\hline Jenis Variabel & Nama Variabel & Simbol & $\begin{array}{c}\text { Definisi Operasional } \\
\text { Variabel }\end{array}$ & Sumber \\
\hline $\begin{array}{l}\text { Variabel } \\
\text { dependen }\end{array}$ & $\begin{array}{c}\text { Tobin's Q } \\
\text { Economic value added } \\
\text { per share }\end{array}$ & $\begin{array}{c}\mathrm{Q} \\
\text { EVAPS }\end{array}$ & $\begin{array}{l}\text { Nilai pasar/total asset } \\
\text { (Laba setelah pajak-biaya } \\
\text { modal)/total ekuitas }\end{array}$ & $\begin{array}{l}\text { (Xia \& } \\
\text { Wang, } \\
\text { 2020) }\end{array}$ \\
\hline \multirow{2}{*}{$\begin{array}{l}\text { Variabel } \\
\text { independen }\end{array}$} & $\begin{array}{l}\text { Pengungkapan } \\
\text { informasi lingkungan }\end{array}$ & EID & $\begin{array}{l}\text { Logaritma natural total biaya } \\
\text { lingkungan }\end{array}$ & $\begin{array}{l}\text { (Basuki \& } \\
\text { Irwanda, } \\
\text { 2018) }\end{array}$ \\
\hline & $\begin{array}{l}\text { Pengungkapan } \\
\text { informasi inovasi } \\
\text { teknologi }\end{array}$ & TIID & $\begin{array}{l}\text { Logaritma natural total biaya } \\
\text { R\&D }\end{array}$ & $\begin{array}{l}\text { (Zang et al., } \\
\text { 2019) }\end{array}$ \\
\hline \multirow{4}{*}{ Variabel kontrol } & Ukuran perusahaan & Size & $\begin{array}{l}\text { Logaritma natural pada aset di } \\
\text { akhir tahun }\end{array}$ & \multirow{4}{*}{$\begin{array}{l}\text { (Xia \& } \\
\text { Wang, } \\
\text { 2020) }\end{array}$} \\
\hline & Aset dan liabilitas & Lev & Total utang/total asset & \\
\hline & $\begin{array}{l}\text { Pertumbuhan } \\
\text { perusahaan }\end{array}$ & Growth & $\begin{array}{l}\text { Tingkat pertumbuhan } \\
\text { pendapatan kotor operasional } \\
\text { tahunan }\end{array}$ & \\
\hline & $\begin{array}{l}\text { Konsentrasi } \\
\text { kepemilikan }\end{array}$ & OC & $\begin{array}{l}\text { Jumlah rasio } \\
\text { saham diluar } \\
\text { masyarakat }\end{array}$ & \\
\hline
\end{tabular}

Data yang akan digunakan dalam uji regresi harus lolos dalam uji stasioner. Uji stasioner dalam penelitian ini diamati melalui metode Uji Phillips Person. Berdasarkan hasil analisis, data yang digunakan untuk mengukur seluruh variabel pada derajat level I(0) yang ditunjukkan masing-masing variabel dengan nilai prob. lebih kecil daripada tingkat signifikansi alfa 0.05 persen. Sehingga dapat disimpulkan bahwa data yang digunakan untuk semua variabel telah bersifat stasioner atau data telah memiliki varians yang tidak terlalu besar dan kecenderungan untuk mendekati nilai rata-ratanya sehingga baik dalam pengujian selanjutnya. Uji spesifikasi model harus dilakukan terlebih dahulu untuk menentukan model yang harus digunakan. Uji spesifikasi model dilakukan untuk memperoleh model terbaik dalam regresi data panel. Pada uji chow, ditemukan bahwa seluruh model yang digunakan memperoleh hasil sebagai data fixed effect model. Maka dari itu, hausman test perlu dilakukan untuk menentukan model terbaik yang harus digunakan antara random effect atau fixed effect.

Berdasarkan hasil tersebut analisis data, model yang tepat yang harus digunakan untuk hipotesis 1 adalah model random effect dimana nilai Probabilitas dari Chi square yang diperoleh sebesar sebesar $0.0229>0,05$. Dengan demikian hipotesa nol $\left(\mathrm{H}_{0}\right)$ ditolak, sehingga model yang lebih baik digunakan adalah estimasi dengan fixed effect. Kemudian model yang tepat yang harus digunakan untuk hipotesis 2 adalah model fixed effect dimana nilai Probabilitas dari Chi square sebesar $0.0010<0,05$. Dengan demikian hipotesa nol $\left(\mathrm{H}_{0}\right)$ ditolak. Pada hipotesis 3, nilai Probabilitas dari Chi square sebesar $0.6929>$ 
0,05. Dengan demikian hipotesa nol $\left(\mathrm{H}_{0}\right)$ ditolak, sehingga model yang lebih baik digunakan adalah estimasi dengan random effect. Sedangkan untuk hipotesis 4 yang digambarkan melalui 2 model menunjukkan masing-masing nilai Probabilitas dari Chi square sebesar 0.0037<0,05 dan 0.7947 > 0,05. Dengan demikian hipotesa nol $\left(\mathrm{H}_{0}\right)$ ditolak dan diterima, sehingga model yang lebih baik digunakan adalah estimasi dengan random effect dan fixed effect. Uji statistik deskriptif ini dilakukan dengan tujuan untuk memberikan deskripsi dari setiap variabel, di mana hasil dari pengujian ini dapat dilihat dari rata rata (mean), nilai tengah (median), nilai maksimum, nilai minimum dan standar deviasi.

\section{HASIL DAN PEMBAHASAN}

\section{Hasil}

Statistik deskriptif menjelaskan tentang karakteristik data yang digunakan dalam penelitian yang dilihat dari nilai minimum, maksimum, mean, dan standar deviasi. Nilai minimum merupakan nilai terendah untuk setiap variabel, sedangkan nilai maksimum merupakan nilai tertinggi untuk setiap variabel dalam penelitian. Nilai mean merupakan nilai rata-rata dari setiap variabel dalam penelitian. Standar deviasi merupakan sebaran data penelitian yang digunakan untuk mencerminkan data itu heterogen atau homogen yang bersifat fluktuatif. Statistik deskriptif dari hasil pengolahan Eviews 9.0. Variabel Tobin's Q memiliki nilai minimum sebesar 0,0715 dan nilai maksimum sebesar 12,7531 sedangkan nilai rata-ratanya sebesar 1.6822 dengan nilai standar deviasi sebesar 2,1092. Kemudian EVAPS memiliki nilai minimum sebesar -2.516,49 dan nilai maksimum sebesar 4.509,97 dengan nilai rataratanya sebesar $-53,9052$ dan nilai standar deviasi sebesar 590,205, sedangkan rata-rata EID dan TTID masing-masing sebesar 21,6335 dan 22,0638. Rata - rata Size adalah 29,1975, Lev adalah 0,3965 dan Growth adalah -12,5794 di dalam sampel tersebut. Uji t pada hipotesis 1 disajikan pada Tabel 3.

Tabel 3. Hasil Estimasi Metode Fixed Effect Variabel Dependen: EID

\begin{tabular}{cccc}
\hline Variabel & Coeficient & Prob. & Keputusan \\
\hline TIID & $-0,0121$ & 0,9296 & Tidak Berpengaruh \\
Lev & $-0,5376$ & 0,5321 & Tidak Berpengaruh \\
Size & 0,0586 & 0,8589 & Tidak Berpengaruh \\
Growth & $-1,300$ & 0,9671 & Tidak Berpengaruh \\
OC & 2,8750 & 0,4821 & Tidak Berpengaruh \\
\hline
\end{tabular}

Pengujian Statistik menunjukkan besarnya nilai sig. TIID sebesar $0.9296>0,10(\alpha=10 \%)$, maka dapat disimpulkan hipotesa null $\left(\mathrm{H}_{0}\right)$ diterima, $\mathrm{H}_{\mathrm{a}}$ ditolak. Oleh karena itu disimpulkan pada tingkat kepercayaan 90 persen tidak terdapat pengaruh TIID terhadap EID. Hasil penelitian pengungkapan informasi inovasi teknologi tidak berpengaruh terhadap pengungkapan informasi lingkungan ini tidak mendukung penelitian Wang, Wang, Wang, dan Yang (2020). Hal ini menunjukkan bahwa pengungkapan informasi research and development yang dilakukan oleh perusahaan tidak akan memiliki dampak terhadap pengungkapan informasi lingkungan.

Pada variabel kontrol, secara keseluruhan memiliki nilai sig. > 0,05 yang berarti bahwa variabel kontrol yang digunakan seperti leverage, size, growth dan ownership company belum memiliki pengaruh terhadap tingkat pelaporan lingkungan perusahaan. Artinya, setiap kenaikan atau penurunan nilai leverage, size, growth maupun ownership company tidak akan membuat berdampak terhadap biaya yang harus dikeluarkan oleh perusahaan terkait dengan lingkungan. Hal ini berkaitan dengan banyak perusahaan yang sudah melaporkan dan mengeluarkan biaya yang besar untuk menanggulangi dampak lingkungan yang diberikan namun berbeda dengan biaya yang dikeluarkan untuk research and development nya. Dari data yang diperoleh, pengeluaran biaya terhadap penelitian dan pengembangan tidak bisa ditentukan apakah akan berkaitan dengan biaya yang akan dikeluarkan untuk lingkungan. Uji $t$ pada hipotesis 2 disajikan pada Tabel 4.

Tabel 4. Hasil Estimasi Metode Fixed Effect Variabel Dependen: Q

\begin{tabular}{cccc}
\hline Variabel & Coeficient & Prob. & Keputusan \\
\hline EID & 0,1138 & 0,4258 & Tidak Berpengaruh \\
TIID & 0,1868 & 0,3572 & Tidak Berpengaruh \\
Lev & 3,5298 & 0,0063 & Berpengaruh Positif \\
Size & $-1,2435$ & 0,0117 & Berpengaruh Negatif \\
Growth & 2,2400 & 0,9616 & Tidak Berpengaruh \\
OC & $-5,3302$ & 0,3776 & Tidak Berpengaruh \\
\hline
\end{tabular}


Berdasarkan Tabel 3 dan Tabel 4 menjelaskan mengenai hasil terhadap hipotesis 2 namun berfokus pada variabel pengungkapan informasi lingkungan. Pada hasil uji statistik tabel 9, besarnya nilai sig. EID sebesar $0.4528>0.10$ maka dapat disimpulkan variabel pengungkapan informasi lingkungan tidak memiliki pengaruh terhadap kinerja keuangan yang diukur melalui Tobin's Q. Kemudian, pada hasil uji statistik tabel 10, besarnya nilai sig. EID sebesar $0.7216>0.10$. Hal ini berarti pengungkapan informasi mengenai biaya lingkungan yang dilakukan perusahaan tidak akan mempengaruh tingkat kinerja keuangan dari perusahaan itu sendiri yang diukur melalui nilai tambah ekonomi per saham. Baik pengukuran kinerja keuangan menggunakan tobin's q maupun dari tambah ekonomi per saham menunjukkan tidak adanya pengaruh. Hasil ini tidak mendukung hasil dari penelitian sebelumnya yang dilakukan oleh Xie, Nozawa, Yagi, Fujii dan Managi (2019) yang memperoleh hasil bahwa perusahaan dengan kebijakan lingkungan yang tunduk pada penilaian independen cenderung lebih efisien dan sangat di evaluasi. Persaingan pasar yang ketat mendorong perusahaan untuk menerapkan kebijakan lingkungan yang lebih strategis untuk meningkatkan daya saing.

Berdasarkan tabel 4, variabel kontrol yaitu leverage memiliki pengaruh positif dan size memiliki pengaruh negatif dengan nilai signifikansi masing-masing sebesar sebesar 0.0063 dan $0.0117<0.10$ dengan nilai koefisien sebesar 3.5298 untuk leverage dan -1.2435 untuk size. Maka dapat disimpulkan bahwa leverage memiliki pengaruh positif yang mengartikan jika nilai leverage naik sebesar 1 persen maka nilai Tobin;s Q akan naik sebesar 3.5298. Hal ini menunjukkan bahwa perusahaan harus meningkatkan jumlah pembiayaan atau pengambilan hutang agar kinerja keuangan perusahaan semakin meningkat. Tentu saja dengan adanya peningkatan utang maka perusahaan harus siap akan resiko yang tinggi. Namun jika nilai size naik sebesar 1 persen maka nilai Tobin's Q akan turun sebesar 1.2435. Hal ini menandakan bahwa perusahaan harus mengatur aset yang ada. Semakin tinggi aset maka kinerja keuangan perusahaan akan semakin menurun. Jika dilihat dari segi piutang yang merupakan aset perusahaan, maka perusahaan harus mengatur perputaran piutang sehingga bisa menurunkan aset. Tentu saja hal ini baik untuk perusahaan dikarenakan dapat mengatur kapan piutang tersebut dapat dibayarkan oleh konsumen. Sedangkan untuk variabel kontrol growth dan ownership company tidak memiliki pengaruh terhadap kinerja keuangan yang diukur melalui Tobin's Q. Hasil ini bisa disebabkan karena pendapatan kotor yang diterima perusahaan belum sepenuhnya memiliki nilai yang menandakan bahwa perusahaan memiliki keuntungan. Dari keuntungan tersebut perusahaan bisa melakukan investasi maupun penambahan aset sedangkan ownership company dikarenakan tingkat kepemilikan perusahaan tidak berubah secara signifikan dari tahun ke tahun walaupun terjadi keuntungan maupun kerugian. Uji $t$ pada hipotesis 3 disajikan pada Tabel 5.

Tabel 5. Hasil Estimasi Metode Random Effect Variabel Dependen: EVAPS

\begin{tabular}{cccc}
\hline Variabel & Coeficient & Prob. & Keputusan \\
\hline EID & $-24,4149$ & 0,7216 & Tidak Berpengaruh \\
TIID & 1,4673 & 0,9880 & Tidak Berpengaruh \\
Lev & 304,3686 & 0,6174 & Tidak Berpengaruh \\
Size & 159,5629 & 0,4946 & Tidak Berpengaruh \\
Growth & 0,4189 & 0,0630 & Berpengaruh Positif \\
OC & 1468,611 & 0,6121 & Tidak Berpengaruh \\
\hline
\end{tabular}

Berdasarkan Tabel 4 dan Tabel 5 menjelaskan mengenai hasil terhadap hipotesis 3 namun berfokus pada variabel pengungkapan informasi inovasi teknologi. Pada hasil uji statistik tabel 4 , besarnya nilai sig. TIID sebesar $0.3572>0.10$ maka dapat disimpulkan variabel pengungkapan informasi inovasi teknologi tidak memiliki pengaruh terhadap kinerja keuangan yang diukur melalui economiv value added per share. Kemudian, pada hasil uji statistik tabel 5, besarnya nilai sig. TIID sebesar $0.9880>$ 0.10. Hal ini berarti pengungkapan informasi mengenai biaya inovasi teknologi yang dilakukan perusahaan tidak akan mempengaruh tingkat kinerja keuangan dari perusahaan itu sendiri yang diukur melalui nilai tambah ekonomi per saham. Baik pengukuran kinerja keuangan menggunakan tobin's q maupun dari tambah ekonomi per saham menunjukkan tidak adanya pengaruh.

Berdasarkan tabel 10, variabel kontrol yaitu growth memiliki pengaruh positif dan dengan nilai signifikansi sebesar $0.0630<0.10$ dengan nilai koefisien sebesar 0.4189 . Maka dapat disimpulkan bahwa Growth memiliki pengaruh positif yang mengartikan jika nilai growth naik sebesar 1 persen maka nilai economic value added per share akan naik sebesar 0.4189. Semakin baik nilai pertumbuhan perusahaan yang diukur melalui pendapatan kotor perusahaan maka akan meningkatkan kinerja keuangan perusahaan dari segi nilai tambah ekonomi. Hal ini dikarenakan pendapatan kotor perusahaan sangat berkaitan erat dengan nilai tambah ekonomi suatu perusahaan. Pendapatan kotor perusahaan yang tinggi namun dengan pengeluaran yang sedikit menandakan bahwa perusahaan tersebut memperoleh laba yang 
tinggi. Sedangkan untuk variabel kontrol leverage, size dan ownership company tidak memiliki pengaruh terhadap kinerja keuangan yang diukur melalui economic value added per share. Hal ini bisa terjadi dikarenakan perusahaan menjalankan operasionalnya tidak menggunakan aset yang diperoleh dari utang sehingga pendapatan yang diperoleh tidak di ikuti dengan jumlah beban bunga yang harus dibayarkan oleh perusahaan. Kemudian untuk growth, pendapatan kotor yang diterima perusahaan belum sepenuhnya memiliki nilai yang menandakan bahwa perusahaan memiliki keuntungan. Dari keuntungan tersebut perusahaan bisa melakukan investasi maupun penambahan aset sedangkan ownership company dikarenakan tingkat kepemilikan perusahaan tidak berubah secara signifikan dari tahun ke tahun walaupun terjadi keuntungan maupun kerugian. Uji t pada hipotesis 4 disajikan pada Tabel 6.

Tabel 6. Hasil Estimasi Metode Fixed Effect Variabel Dependen: Q

\begin{tabular}{cccc}
\hline Variabel & Coeficient & Prob. & Keputusan \\
\hline EID & 0,1949 & 0,8930 & Tidak Berpengaruh \\
TIID & 0,2659 & 0,8516 & Tidak Berpengaruh \\
EIDTIID & $-0,0037$ & 0,9552 & Tidak Berpengaruh \\
Lev & 3,5392 & 0,0068 & Berpengaruh Positif \\
Size & $-1,2373$ & 0,0148 & Berpengaruh Negatif \\
Growth & 2,0000 & 0,9661 & Tidak Berpengaruh \\
OC & $-5,3372$ & 0,3793 & Tidak Berpengaruh \\
\hline
\end{tabular}

Tabel 7. Hasil Estimasi Metode Random Effect Variabel Dependen: EVAPS

\begin{tabular}{cccc}
\hline Variabel & Coeficient & Prob. & Keputusan \\
\hline EID & 222,0881 & 0,7496 & Tidak Berpengaruh \\
TIID & 241,7768 & 0,7230 & Tidak Berpengaruh \\
EIDTIID & $-11,3380$ & 0,7219 & Tidak Berpengaruh \\
Lev & 332,9413 & 0,5895 & Tidak Berpengaruh \\
Size & 178,2017 & 0,4585 & Tidak Berpengaruh \\
Growth & 0,4115 & 0,0700 & Berpengaruh Positif \\
OC & 1447,115 & 0,6189 & Tidak Berpengaruh \\
\hline
\end{tabular}

Tabel 6 dan Tabel 7 akan menjelaskan mengenai hasil terhadap hipotesis 4. Pada hasil uji statistik. Berdasarkan hasil tabel 6, besarnya nilai sig. EIDTIID sebesar $0.9552>0.10$ maka dapat disimpulkan variabel sinergis antara tingkat pengungkapan informasi lingkungan dan pengungkapan inovasi teknologi tidak memiliki pengaruh terhadap kinerja keuangan yang diukur melalui Tobin's Q. Kemudian, pada hasil uji statistik Tabel 7, besarnya nilai sig. EIDTIID sebesar 0.7219>0.10. Hal ini berarti sinergis antara pengungkapan informasi biaya lingkungan dan inovasi teknologi yang dilakukan perusahaan tidak akan mempengaruh tingkat kinerja keuangan dari perusahaan itu sendiri yang diukur melalui economic value added per share. Artinya, hasil ini tidak bisa menjelaskan apakah dengan adanya sinergis antara tingkat pengungkapan informasi lingkungan dan inovasi teknologi bisa menyebabkan kinerja keuangan perusahaan semakin menurun.

Berdasarkan tabel 6, variabel kontrol yaitu leverage memiliki pengaruh positif dan size memiliki pengaruh negatif dengan nilai signifikansi masing-masing sebesar sebesar 0.0068 dan $0.0148<0.10$ dengan nilai koefisien sebesar 3.5392 untuk leverage dan -1.2373 untuk size. Maka dapat disimpulkan bahwa leverage memiliki pengaruh positif yang mengartikan jika nilai leverage naik sebesar 1 persen maka nilai Tobin;s Q akan naik sebesar 3.5392. Hal ini menunjukkan bahwa Namun jika nilai size naik sebesar 1 persen maka nilai Tobin's Q akan turun sebesar 1.2373. Sedangkan untuk variabel kontrol growth dan ownership company tidak memiliki pengaruh terhadap kinerja keuangan yang diukur melalui Tobin's Q. Kemudian Berdasarkan tabel 12, variabel kontrol yaitu growth memiliki pengaruh positif dan dengan nilai signifikansi sebesar $0.0700<0.10$ dengan nilai koefisien sebesar 0.4115. Maka dapat disimpulkan bahwa Growth memiliki pengaruh positif yang mengartikan jika nilai growth naik sebesar 1 persen maka nilai economic value added per share akan naik sebesar 0.4115. Sedangkan untuk variabel kontrol leverage, size dan ownership company tidak memiliki pengaruh terhadap kinerja keuangan yang diukur melalui economic value added per share.

\section{Pembahasan}

Pengungkapan informasi dapat digunakan untuk menurunkan biaya agensi, untuk mengurangi asimetri informasi antara perusahaan dan penyedia dana, dan untuk mengurangi biaya politik (Dutrianda \& Pangaribuan, 2020; Sihombing et al., 2017). Alasan kecenderungan perusahaan besar untuk 
mengungkapkan lebih banyak informasi dijelaskan bahwa biaya akumulasi dan pengungkapan informasi tidak tinggi dibandingkan dengan perusahaan kecil, manajemen perusahaan yang lebih besar kemungkinan besar akan menyadari kemungkinan manfaat dari pengungkapan informasi, seperti kemampuan pemasaran yang lebih besar dan kemudahan pendanaan yang lebih besar; perusahaan yang lebih kecil mungkin merasa bahwa pengungkapan informasi penuh dapat membahayakan posisi kompetitif mereka. Selain itu, karena perusahaan besar lebih terekspos pada pengawasan publik daripada perusahaan kecil, mereka cenderung mengungkapkan lebih banyak informasi. Perusahaan besar cenderung lebih kompleks dan kompleksitas memerlukan lebih banyak pengungkapan (Ikhwandarti et al., 2010; Nassreddine, 2016). Banyak penelitian sebelumnya telah mendukung hubungan positif antara ukuran perusahaan dan tingkat pengungkapan sukarela.

Keterbukaan informasi menjadi media dimana perusahaan dapat mengkomunikasikan informasi penting seperti hasil usaha, pelaksanaan tanggungjawab, dan pengendalian risiko kepada pemegang saham dan subyek terkait lainnya seperti masyarakat. Dalam "hubungan agen" di mana kepemilikan dan hak manajemen dipisahkan (Páez-Pérez \& Sánchez-Silva, 2016). Jumlah dan kualitas informasi aktual yang diperoleh oleh investor dan manajer perusahaan, dikarenakan lingkungan dan posisi yang berbeda, seperti adanya manajer yang memiliki "bahaya moral" (Byford, 2017; Hoppe \& Schmitz, 2018). Semua ini akan menyebabkan asimetri dalam perolehan informasi oleh kedua pihak (Jeon, 2019). Didukung oleh teori transmisi sinyal, manajer bisnis dapat mengurangi kesenjangan antara kedua pihak dan mengurangi biaya agensi dengan cara memaksimalkan pengungkapan informasi (Liang et al., 2019). Menurut "teori pemangku kepentingan", perusahaan dapat mencapai komunikasi yang baik dengan pemangku kepentingan melalui keterbukaan informasi dengan menunjukkan keunggulan kompetitif mereka dan menarik sumber daya, sekaligus mengurangi risiko kehilangan sumber daya tersebut (De Gooyert, et al., 2017). Selain itu, dampak ekonomi spesifik dari pengungkapan informasi perusahaan juga harus mempertimbangkan karakteristik industri dan lingkungan kebijakan makro.

Tren tingkat pengungkapan informasi perlindungan lingkungan dan informasi inovasi teknologi perusahaan harus konsisten secara teoritis apabila harus dijelaskan dari segi motivasi pengungkapan. Perlindungan lingkungan dan inovasi teknologi keduanya merupakan cerminan dari daya saing dan potensi pengembangan perusahaan, dan sebagian besar informasi yang diungkapkan perusahaan secara sukarela bermanfaat bagi diri mereka sendiri (Gobbo et al., 2018; Yin et al., 2018). Selain mencerminkan perlindungan lingkungan dan hasil inovatif di periode sebelumnya, hal tersebut juga dapat membangun kepercayaan pemegang saham pada manajer dan pengakuan mereka atas potensi pengembangan masa depan perusahaan.

Manajer keuangan harus memperhatikan terkait tingkat aset, utang dan pendapatan kotor perusahaan dikarenakan adanya pengaruh dari ketiga hal ini (Miswanto, 2013; Respati, 2011). Perusahaan perlu untuk mengatur agar utang yang diperoleh bisa digunakan untuk keperluan operasional perusahaan contohnya seperti pembelian aset tetap untuk efektifitas operasi (Hakim et al., 2017; Satria \& Fatmawati, 2021). Kemudian perlu adanya perhatian terhadap tingkat perputaran piutang sehingga aset perusahaan tidak mengalami kenaikan yang signifikan khususnya belum tertagihnya hasil dari penjualan yang dilakukan. Selanjutnya manajer keuangan harus meningkatkan penjualan dengan memperhatikan efisiensi dari penggunaan biaya operasi sehingga total pendapatan kotor akan semakin meningkat. Investor harus memperhatikan utang, aset dan pendapatan kotor perusahaan sebelum memutuskan untuk berinvestasi pada perusahaan tersebut. Hal ini dikarenakan aset perusahaan bisa saja tinggi namun hal itu terjadi dikarenakan perusahaan belum mampu untuk menagih piutang dari konsumen. Kemudian investor juga harus memperhitungkan terkait utang yang dimiliki perusahaan apakah sudah digunakan secara menyeluruh untuk keperluan operasi atau tidak (Piñeiro-Chousa et al., 2020; Saerang et al., 2014). Tentunya hal ini bisa dilihat oleh investor melalui total pendapatan kotornya perusahaan. Efisiensi dari penggunaan utang tersebut bisa ditunjukkan dengan semakin bertambahnya utang maka semakin naik total pendapatan kotor perusahaan.

Dalam Penelitian ini, terdapat beberapa keterbatasan atau kelemahan, diantaranya adalah perusahaan yang menjadi objek penelitian hanya berjumlah 28 perusahaan. Hal ini dikarenakan perusahaan dalam sektor manufaktur yang dipilih tidak semuanya memenuhi kriteria seperti tidak melaporkan berapa jumlah biaya yang dikeluarkan perusahaan untuk lingkungan dan R\&D. Keterbatasan lainnya yaitu tidak semua perusahaan membagikan dividen setiap tahun dan tidak semua perusahaan memiliki biaya keuangan atau biaya bunga yang menjadi salah satu indikator pengukuran variabel. Berdasarkan kesimpulan yang telah diperoleh maka diberikan saran yang sekiranya dapat membantu penelitian selanjutnya yaitu penelitian selanjutnya bisa menggunakan variabel yang tidak digunakan dalam penelitian ini. Contohnya seperti struktur modal yang diukur melalui Return on Equity (ROE). Vătavu (2015) memperoleh hasil bahwa ROE berpengaruh negatif signifikan terhadap kinerja keuangan perusahaan manufaktur. 


\section{SIMPULAN}

Variabel pengungkapan informasi perlindungan lingkungan tidak memiliki pengaruh terhadap tingkat pengungkapan informasi inovasi teknologi perusahaan manufaktur di Indonesia tahun 2015-2019. Variabel pengungkapan informasi perlindungan lingkungan tidak memiliki pengaruh terhadap kinerja keuangan perusahaan manufaktur di Indonesia tahun 2015-2019. Sinergis antara tingkat pengungkapan informasi perlindungan lingkungan dan inovasi teknologi tidak memiliki pengaruh terhadap kinerja keuangan perusahaan manufaktur tahun 2015-2019.

\section{DAFTAR PUSTAKA}

Anis, I. (2017). Pengaruh Pengungkapan Csr Terhadap Pelaporan Pajak Agresif, Dan Pengaruhnya Terhadap Return Saham. Jurnal ASET (Akuntansi Riset), 9(1). https://doi.org/10.17509/jaset.v9i1.5258.

Azhari, M., \& Agus, F. (2016). Analisa kebutuhan sistem informasi manajemen perusahaan kayu ukir (SIMPKU) (study kasus CV. Embed). Informatika Mulawarman: Jurnal Ilmiah Ilmu Komputer, 11(1), 49. https://doi.org/10.30872/jim.v11i1.204.

Basuki, B., \& Irwanda, R. D. (2018). Environmental cost analysis and reporting to measure environmental performance in realizing eco-efficiency at PT Industri Kereta Api (Persero). Asian Journal of Accounting Research, 3(2), 169-180. https://doi.org/10.1108/ajar-06-2018-0013.

Bour, K. B., Asafo, A. J., \& Kwarteng, B. O. (2019). Study on the effects of sustainability practices on the growth of manufacturing companies in urban Ghana. Heliyon, 5(6). https://doi.org/10.1016/j.heliyon.2019.e01903.

Byford, M. C. (2017). Moral hazard in strategic decision making. International Journal of Industrial Organization, 55, 114-136. https://doi.org/10.1016/j.ijindorg.2017.10.001.

de Gooyert, V., Rouwette, E., van Kranenburg, H., \& Freeman, E. (2017). Reviewing the role of stakeholders in Operational Research: A stakeholder theory perspective. European Journal of Operational Research, 262(2), 402-410. https://doi.org/10.1016/j.ejor.2017.03.079.

Dewi, P. A. C., \& Sedana, I. B. P. (2019). Pengaruh Profitabilitas, Ukuran Perusahaan, Dan Leverage Terhadap Pengungkapan Corporate Social Responsibility. E-Jurnal Manajemen, 8(11). https://doi.org/10.24843/EJMUNUD.2019.v08.i11.p12.

Dutrianda, fki P. D. N., \& Pangaribuan, H. (2020). Pengungkapan Informasi Modal Intelektual, Nilai Perusahaan dan Harga Saham. InFestasi: Jurnal Bisnis Dan Akuntansi, 16(2). https://doi.org/10.21107/infestasi.v16i2.8971.

Efrizon, E. (2019). Pengaruh Rasio Keuangan Terhadap Harga Saham Perusahaan Otomotif Periode 20132017. Jurnal Akuntansi Aktua, 6(1). https://doi.org/10.17977/um004v5i32019p250.

Fadrianto, I. P., \& Mulyani, S. D. (2018). Pengaruh Manajemen Risiko Dan Karakteristik Perusahaan Terhadap Penghindaran Pajak Dengan Pengungkapan Corporate Social Responsibility Sebagai Variabel Moderasi. Jurnal Ilmiah Akuntansi, 4(2), 72-78. https://doi.org/10.32528/psneb.v0i0.5194.

Gobbo, J. A., Busso, C. M., Gobbo, S. C. O., \& Carreão, H. (2018). Making the links among environmental protection, process safety, and industry 4.0. Process Safety and Environmental Protection, 117, 372-382. https://doi.org/10.1016/j.psep.2018.05.017.

Gong, Y. (2019). Information quality choice and information disclosure in oligopoly. Research in Economics, 73(3), 216-224. https://doi.org/10.1016/j.rie.2019.07.002.

Hakim, Z., Handajani, L., \& Inapty, B. A. (2017). Voluntary Tax Compliance Wajib Pajak Perusahaan Perhotelan: Determinan, Kepercayaan Dan Kekuasaan Legitimasi. Jurnal Akuntansi, 21(2). https://doi.org/10.24912/ja.v21i2.198.

Hoppe, E. I., \& Schmitz, P. W. (2018). Hidden action and outcome contractibility: An experimental test of moral hazard theory. Games and Economic Behavior, 109, 544-564. https://doi.org/10.1016/j.geb.2018.02.006.

Ikhwandarti, F., Pratolo, S., \& Suryanto, R. (2010). Pengaruh Karakteristik Perusahaan Terhadap Nilai Perusahaan Dan Pengungkapan Informasi Sosial Sebagai Variabel Intervening. Jurnal Accounting and Investment, 11(1).

Jeon, H. (2019). Patent protection and R\&D subsidy under asymmetric information. International Review of Economics and Finance, 62(July 2018), 332-354. https://doi.org/10.1016/j.iref.2019.04.001.

Khairul, K., Mariance, H., \& Manullang. (2020). Komparasi Logam Berat pada Kawasan Mangrove Alami dan Industri di Perairan Belawan, Pulau Sicanang. Chemical Engineering Research Articles, 3(1). https://doi.org/10.25273/cheesa.v3i1.6033.

Kusa, R., Duda, J., \& Suder, M. (2022). How to sustain company growth in times of crisis: The mitigating 
role of entrepreneurial management. Journal of Business Research, 142. https://doi.org/10.1016/j.jbusres.2021.12.081.

Kusuma, I. L. (2016). Pengaruh Asset Growth, Debt To Equity Ratio, Return On Equity, Total Asset Turnover Dan Earning Per Share Terhadap Beta Saham Pada Perusahaan Yang Masuk Dalam Kelompok Jakarta Islamic Index (Jii) Periode 2013-2015. Jurnal Riset Akuntansi Dan Keuangan, 4(2). https://doi.org/10.17509/jrak.v4i2.4034.

Liang, S., Li, H., Liu, X., \& Schuckert, M. (2019). Motivators behind information disclosure: Evidence from Airbnb hosts. Annals of Tourism Research, 76(March), 305-319. https://doi.org/10.1016/j.annals.2019.03.001.

Mahanani, A., Titisari, K. H., \& Nurlaela, S. (2017). Pengaruh Karateristik Perusahaan, Sales Growth, dan CSR Terhadap Tax Avoidance. IENACO, 732-742. https: //doi.org/10.21460/jrak.2018.141.294.

Minutolo, M. C., Kristjanpoller, W. D., \& Stakeley, J. (2019). Exploring environmental, social, and governance disclosure effects on the S\&P 500 financial performance. Business Strategy and the Environment, 28(6), 1083-1095. https://doi.org/10.1002/bse.2303.

Mirza, F. M., Rizvi, S. B.-U.-H., \& Bergland, O. (2021). Service quality, technical efficiency and total factor productivity growth in Pakistan's post-reform electricity distribution companies. Utilities Policy, 68. https://doi.org/10.1016/j.jup.2020.101156.

Miswanto, M. (2013). Pengukuran Risiko Bisnis Dan Risiko Pendanaan Dalam Perusahaan. Jurnal Economia, 9(1). https://doi.org/10.21831/economia.v9i1.1380.

Mitrega, M., Siemieniako, D., Makkonen, H., Kubacki, K., \& Bresciani, S. (2021). Versatile capabilities for growth in the context of transforming countries: Evidence from Polish manufacturing companies. Journal of Business Research, 134. https://doi.org/10.1016/j.jbusres.2021.05.038.

Nassreddine, G. (2016). Determinants of financial information disclosure: A visualization test by cognitive mapping technique. Journal of Economics, Finance and Administrative Science, 21(40), 8-13. https://doi.org/10.1016/j.jefas.2016.03.002.

Páez-Pérez, D., \& Sánchez-Silva, M. (2016). A dynamic principal-agent framework for modeling the performance of infrastructure. European Journal of Operational Research, 254(2), 576-594. https://doi.org/10.1016/j.ejor.2016.03.027.

Peng, H., \& Liu, Y. (2018). How government subsidies promote the growth of entrepreneurial companies in clean energy industry: An empirical study in China. Journal of Cleaner Production, 188(1). https://doi.org/10.1016/j.jclepro.2018.03.126.

Piñeiro-Chousa, J., López-Cabarcos, M. Á., \& Ribeiro-Soriano, D. (2020). Does investor attention influence water companies' stock returns? Technological Forecasting and Social Change, 158. https://doi.org/10.1016/j.techfore.2020.120115.

Purwanti, S. M., \& Sugiyarti, L. (2017). Pengaruh Intensitas Aset Tetap, Pertumbuhan Penjualan Dan Koneksi Politik Terhadap Tax Avoidance (Studi Kasus Pada Perusahaan Manufaktur Yang Terdaftar Di Bursa Efek Indonesia Tahun 2012-2016). Jurnal Riset Akuntansi Dan Keuangan, 5(3). https://doi.org/10.17509/jrak.v5i3.9225.

Respati, N. W. T. (2011). Pengaruh Locus Of Control Terhadap Hubungan Sikap Manajer, Norma-Norma Subyektif, Kendali Perilaku Persepsian, Dan Intensi Manajer Dalam Melakukan Kecurangan Penyajian Laporan Keuangan. JAKI (Jurnal Akuntansi Dan Keuangan Indonesia), 8(2). https://doi.org/10.21002/jaki.2011.08.

Saerang, I., Tommy, P., \& Christiano, M. (2014). Analisis Terhadap Rasio-rasio Keuangan Untuk Mengukur Profitabilitas Pada Bank-bank Swasta Yang Go Public Di Bursa Efek Indonesia. Jurnal Riset Ekonomi, Manajemen, Bisnis Dan Akuntansi, 2(4), 817-830. https: //doi.org/10.35794/emba.v2i4.6490.

Satria, M. R., \& Fatmawati, A. P. (2021). Penyusunan Laporan Keuangan Perusahaan Menggunakan Aplikasi Spreadsheet (Pada Pd Beras Padaringan). Fair Value Jurnal Ilmiah Akuntansi Dan Keuangan, 3(2), 146-164. https://doi.org/10.32670/fairvalue.v3i2.146.

Sharif, A., Aloui, C., \& Yarovaya, L. (2020). Pandemi COVID-19, harga minyak, pasar saham, risiko geopolitik, dan perhubungan ketidakpastian kebijakan dalam ekonomi AS: Bukti baru dari pendekatan berbasis wavelet. International Review of Financial Analysis, 70. https://doi.org/10.1016/j.irfa.2020.101496.

Sihombing, J., Agoes, S., \& Santoso, U. (2017). Studi Empiris Terkait Dengan Pengungkapan Sukarela, Kualitas Audit Dan Asimetri Informasi Terhadap Stock Return Pada Perusahaan Manufaktur Yang Terdaftar Pada Bursa Efek Indonesia. Jurnal Akuntansi, 20(1). https://doi.org/10.24912/ja.v21i1.140.

Siregar, S., \& Kiswiranti, D. (2020). Analisis Kualitas Air Tanah Akibat Pengaruh Sungai Klampok Yang Tercemar Limbah Industri Di Kecamatan Bergas Semarang Jawa Tengah (Analysis Of 
Groundwater Quality Due To Effect Klampok River That Was Contaminated Industrial Waste In Bergas Semarang Centra. Jurnal Manusia Dan Lingkungan, 26(1). https: //doi.org/10.22146/jml.39962.

Triyono, T., Yusron, A. L. Al, \& Surojo, E. (2020). Study Pengaruh Kecepatan Pengadukan pada Proses Stir Casting terhadap Sifat Fisik dan Mekanik AMC Berpenguat Pasir Silica yang Dilakukan Proses Electroless Coating. Mekanika: Majalah Ilmiah Mekanika, 19(1). https://doi.org/10.20961/mekanika.v19i1.40248.

Vătavu, S. (2015). The Impact of Capital Structure on Financial Performance in Romanian Listed Companies. Procedia Economics and Finance, 32(15), 1314-1322. https://doi.org/10.1016/s2212-5671(15)01508-7.

Verawaty, Merina, C. I., Jaya, A. K., \& Widianingsih, Y. (2020). Determinants of Environmental Disclosure in Indonesia. 117(Gcbme 2018), 217-226. https://doi.org/10.2991/aebmr.k.200131.047.

Vítková, E., Chovancová, J., \& Veselý, D. (2017). Value Driver and Its Impact on Operational Profit in Construction Company. Procedia Computer Science, 121, 364-369. https://doi.org/10.1016/j.procs.2017.11.049.

Wang, S., Wang, H., Wang, J., \& Yang, F. (2020). Does environmental information disclosure contribute to improve firm financial performance? An examination of the underlying mechanism. Science of the Total Environment, 714(96), 136855. https://doi.org/10.1016/j.scitotenv.2020.136855.

Wardani, D. K., \& Purwaningrum, R. (2018). Pengaruh Karakteristik Perusahaan Dan Corporate Social terhadap Penghindaran Pajak. Jurnal Review AKuntansi Keuangan, 14(1), 1-11. https://doi.org/10.32528/psneb.v0i0.5194.

Wijayanti, A., Wijayanti, A., \& Samrotun, Y. C. (2016). Pengaruh Karakteristik Perusahaan, Gcg Dan Csr Terhadap Penghindaran Pajak. Seminar Nasional IENACO -, 2337-4349.

Xia, D., \& Wang, X. Q. (2020). The synergetic impact of environmental and innovation information disclosure on corporate financial performance: An empirical study based on China coal listed $\begin{array}{lll}\text { companies. } & \text { Technovation, } & \text { February, }\end{array}$ https://doi.org/10.1016/j.technovation.2020.102179.

Xie, J., Nozawa, W., Yagi, M., Fujii, H., \& Managi, S. (2019). Do environmental, social, and governance activities improve corporate financial performance? Business Strategy and the Environment, 28(2), 286-300. https://doi.org/10.1002/bse.2224.

Yin, J., Wang, S., \& Gong, L. (2018). The effects of factor market distortion and technical innovation on China's electricity consumption. Journal of Cleaner Production, 188, 195-202. https://doi.org/10.1016/j.jclepro.2018.03.294.

Yuniarti, D. (2012). Analisis Kesiapan Industri Manufaktur Teknologi Informasi dan Komunikasi (TIK) Dalam Negeri Untuk Mendukung Implementasi Green-ICT Pada Sektor Telekomunikasi. Buletin Pos Dan Telekomunikasi: Media Komunikasi Ilmiah, 10(3). https: //doi.org/10.17933/bpostel.2012.100305.

Zang, Z., Zhu, Q., \& Mogorrón-Guerrero, H. (2019). How does R \& D investment affect the financial performance of cultural and creative enterprises? The moderating effect of actual controller. Sustainability (Switzerland), 11(2). https: //doi.org/10.3390/su11020297. 